\title{
PSYCHOLOGICAL DETERMINANTS OF YOUTH PARTICIPATION IN THE LIFE OF THE COUNTRY
}

\author{
Tatiana Anisimova ${ }^{1}$, Karina Bakuleva ${ }^{2}, \&$ Irina Samuylova ${ }^{2}$ \\ ${ }^{I}$ Department of Human Psychology, Institute of Psychology, The Herzen University (Russian Federation) \\ ${ }^{2}$ Department of Political Psychology, Faculty of Psychology, Saint-Petersburg State University
}

(Russian Federation)

\begin{abstract}
Today's youth as a socio-demographic group is one of the main capital of society, who directly affects on the innovative, creative and labor participation inside each country. A young age is a period when new rights and obligations for direct participation in the political life of society appear, and as a result - the transition from youth to civil maturity, social and legal responsibility.

In November-December 2018, a socio-psychological study was conducted, where the specificity of youth participation in the life of the country were analyzed. 1,000 people aged 18 to 30 years, $65 \%$ - women, residents of 5 countries: Azerbaijan, Armenia, Kyrgyzstan, Moldova and Russia. Methods: questionnaire, method of unfinished sentences, content-analysis. Data processing: primary descriptive statistics, correlation, factor and variance analysis.

The data on the level of knowledge of respondents about the political structure and characteristics of the electoral system of the state were received. The attitude of young people to the electoral process, as well as the priority forms and motives of their participation in political governance were revealed. The analysis of cognitive, emotional and behavioral component of young people's ideas about political elections is carried out.

In general, young people are well informed about their civil rights and responsibilities. Opportunities for participation in political governance are assessed as significant, associated with concern for the surrounding space and positioning of their interests. Elections are seen as an important democratic resource for change within the state, requiring respect for the principles of law and justice.

Youth largely has a degree of mobility, awareness and physical health, which allow it to react quickly and to change behavior, therefore, the identification of universal and specific ways of interaction between young people from different countries with the political system and the priority forms of participation in the life of his country, is particularly relevant.
\end{abstract}

Keywords: Youth, civic activity, participation, election, country.

\section{Introduction}

The youth is a special social-age group, distinguished by the age framework and its status in society: the transition from childhood and adolescence to social responsibility. As a real social group, young people have three main signs of collective subjectivity: interconnectedness, joint activity and group self-reflexivity.

The psychology of youth received the most complete coverage in the age psychology of adolescence. Theoretical models of adolescence are presented in the approaches of leading Soviet psychologists and social educators (L.S. Vygotsky, S.L. Rubinstein, D.B. Elkonin, L.I. Bozovic, I.S. Kon, A.V. Mudrik, I.M. Ilyinsky et al.) and many other scientists (E. Sprangler, S. Buhler, S. Hall, K. Levin, R. Benedict, M. Mead, J. Piaget, E. Erickson, and others) (Volkov, 2006).

The characteristics of young people are determined by their intermediate social position, psychological characteristics of a given age period, the type of social structure, culture and socialization patterns peculiar to a given society, the discrepancy between various types of maturity - physical, mental, sexual, civil and labor (Emmons, 2004).

Political participation in the modern world is understood as actions aimed at exercising the influence of groups and individuals on the political system. Most often, political participation is seen as: the involvement of members of society in political and power relations, in the process of management and 
political decision-making; as the actions of people or groups taken in order to express their interests and influence the content of decisions made at various levels of state power implementation; as an element of political culture and a phenomenon due to the level of economic development and state (stability, transition, crisis) of society (Kirichek, 2011).

Studying the characteristics of political participation and behavior of representatives of various groups, many authors consider it necessary to pay attention to the following psychological components: the needs of the individual and the group participating in the activity; the motives that guide the subject; attitudes, values, orientations, beliefs and goals of the subject; personal characteristics of the role, decision-making style; interpersonal style; cognitive style; proper actions and deeds; feedback between the behavior and the conditions that formed it.

Political participation of young people is activities by which young people can individually or within any political or social movements, organizations, etc., influence the functioning, transformation or development of the political system, thereby defending their own subjectivity in youth policy (Chirun, 2010).

In recent years, the use of mass media to get information about politics, knowledge of current events, participation in political processes have declined among young people in almost all countries with established democratic institutions (Wattenberg, 2006). These changes reflect a decline in both opportunities for participation and civic interest from young people.

The study of the characteristics of the participation of young people in the life of the country is important because the experience of civic activity in youth forms the personality and has a lasting impact on the degree and nature of political participation throughout life (World Development Report 2007..., 2006).

\section{Objectives and design}

The main objective of the research is to study the specificity of the political participation of young people from different countries and psychological determinants of their involvement in politics.

Subject of research: motives, attitudes, cognitions (level of knowledge), political behavior, political participation.

The study was conducted in November-December, 2018, using written and Internet form of special questionnaire.

\section{Methods}

\subsection{Participants}

Young people aged 18 to 30 years from 5 countries: Russia $(n=200)$, Armenia $(n=200)$, Kyrgyzstan $(n=200)$, Moldova $(n=200)$, Azerbaijan $(n=200)$. The total sample size: 1000 respondents. By gender, $35 \%$ - males, $65 \%$ - females.

Age: from 18 to 30 years - acquiring a new status and the formation of basic values. Respondents have sufficient knowledge to interpret social and political factors and civil rights to participate in political elections and other political events.

\subsection{Instruments}

The main research method was a questionnaire method - a method that uses a specially designed questionnaire question list as a means of collecting information from a respondent. The survey was conducted in writing, as well as through a special Internet form (a special link was given to the respondents).

In addition to the socio-demographic characteristics of sample (gender, age, year and direction of education), the questionnaire included:

- questions to identify the level of knowledge of young people about the political system of their country (respondents chose one of three response options: a parliamentary republic, a parliamentary-presidential republic or a presidential republic), electoral system (respondents chose one of three response options: majority, representative or proportional), passive and active electoral law (age to vote and to be elected);

- questions about preferred sources of political information (12 sources at total, measure scale $-\min =1, \max =5)$;

- questionnaire to identify the motives ( 8 items) and forms of political participation (7 items) (based on theoretical approaches of D.Olshansky (2001) and E.Shestopal (2001)), and the most effective forms of citizen participation in political governance $(11$ items), measure scale $-\min =1, \max =5$; 
- a modified version of the method of «Unfinished Proposals», revealing attitudes towards political elections (Samuylova, 2013) (4 items). For high-quality processing of the obtained data, the method of content analysis was used.

Data processing: 1) descriptive statistics methods (means, standard deviation, etc.); 2) the correlation analysis (Pearson), for detecting the presence of connections between the metric variables under study; 3) factor and variance analysis (reduction of dimension). The processing of initial data, calculation of results and statistical analysis were performed using the methods of mathematical statistics included in Microsoft Excel software and IBM SPSS Statistics 23.0.0.

\section{Results and discussion}

Analysis of the data showed that the main sources of information about politics for modern youth are the Internet $(\mathrm{M}=4, \sigma=1.1)$, social networks $(\mathrm{M}=3.73, \sigma=1.23)$, the mass media (television, newspapers, radio) $(\mathrm{M}=3.37, \mathrm{\sigma}=1.28)$ and family $(\mathrm{M}=3.23, \mathrm{\sigma}=1.26)$. The least significant are political parties $(\mathrm{M}=2.58$, $\sigma=1.32)$, political institutes $(M=2.39, \sigma=1.23)$, public organizations $(M=2.38, \sigma=1.16)$, law enforcement agencies $(\mathrm{M}=2.00, \sigma=1.19)$, religious associations, the church $(\mathrm{M}=1.49, \mathrm{\sigma}=0.96)$.

It is said that political parties, political advertising and political institutes create significant electoral information space. At least, they significantly fill the real space, occupy public communication and consume financial resources. The study proved that for young people from different countries information about policies originating from the sources mentioned above is not much important. Thus, it can be assumed that Internet communication becomes the most important player in the electoral field of many countries.

The level of knowledge of young people about the electoral system and the political structure of their country turned out to be quite high (more than $60 \%$ of the correct answers).

Young people quite correctly indicate the age when they can participate in the voting (more than $50 \%$ of the correct answers). This age has already come for them, and they exercised their right, that is, personal experience is well preserved in memory.

Assessing their ability to stand for political elections, the opinions of young people differed more significantly (less than $30 \%$ of correct answers). Also a high percentage of those who find it difficult to answer were received. The revealed lack of knowledge clearly testifies to the absence of formed attitudes to participate in the political life of the country as subjects of politics and a desire to assume leadership functions.

The most manifested among the active forms of youth political participation are electoral behavior $(\mathrm{M}=3.47,6=1.54)$ and the simplest reactions to signals emanating from the political system (the behavior of an observer, a spectator) $(\mathrm{M}=3.07,6=139)$. Coming out with comrades at a public meeting or building barricades is not the leading setting for political participation of young people $(\mathrm{M}=1.59,6=1.08)$. In case of disillusionment with political institutions and rejection of the system, it is more likely that the reaction of switching off from political relations is demonstrated $(M=2.82,6=1.44)$. Among the passive forms of political participation, respondents particularly noted the estrangement from politics due to excessive bureaucratization and disruption of the effective feedback between the political system and civil society as a whole $(\mathrm{M}=2.67, \sigma=1.37)$.

Young people consider the most effective and most likely forms of participation in political management: environmental improvement measures (11.9\%), personal appeals to local governments (11.5\%), collection of signatures, petitions (10.3\%), discussion in the Internet of draft decisions of the authorities $(9.9 \%)$, work in public associations $(9.4 \%)$, participation in municipal elections $(8.1 \%)$. Such an experience of concrete «small deeds» that give a direct visible result can become a strategy for the formation of civic maturity and an active position of the young.

Describing their ideas and understanding «what is elections?», young people pointed out that elections are democracy and the opportunity to choose the future and the best candidate, emphasized the unifying power of the elections themselves for citizens.

Among the reasons for participating in elections, the most common were the answers: «because it is a civic duty», «a way to show one's activity», «to choose a worthy future», «to resist falsification». In their expectations of the election, young people rely on honesty, openness, respect for the legal rules, and the absence of corruption.

On an emotional level, the participation in politics should be meaningful and influential. The perception of elections as predictable, meaningless, not taking into account their interests and desires, push away young people from participating in politics. 
The results of the content analysis of the method of unfinished sentences (attitudes towards elections) were confirmed by quantitative data on the method of measuring motives for political participation. The basic motives for the political participation of young people from different states are the motive of interest $(M=3.04, \sigma=1.64)$, cognition $(M=2.79, \sigma=1.41)$ and world transformations $(\mathrm{M}=2.69,6=1.47)$. Low rates were obtained about motive of power (participation in politics for the getting power) $(\mathrm{M}=1.95, \sigma=1.22)$ and mercantile motive (participation due to monetary reward) $(\mathrm{M}=1.64$, $\sigma=1.14)$. Low rates in terms of the traditional motive of political participation ( $«$ this is customary in their environment, culture») $(\mathrm{M}=1.85, \mathrm{\sigma}=1.21)$ and ideological motive (participation due to agreement with political ideology) $(M=2.26, \sigma=1.32)$ indicate that at this age the formation of their own motivational and value system occurs. This process enhances a critical attitude to the external, «adult» model of values. Young people have enough knowledge and interest in the socio-political situation in the country. Awareness of the inconsistencies with the reality of life principles proclaimed by parents and the environment is manifested in their alienation, revision and idealization of the values of their generation.

Despite the high rates of the motive of world transformation, when answering the question about the possibility to influence oneself on solving the problems of a city or a district, the most common answer was «I don't know I haven't tried yet» (32.4\%). In the second place was the answer «I can, only for some problems» $(29.1 \%)$. In third place was the answer «I can't» $(20.3 \%)$.

The analysis of variance showed that there were no significant differences between respondents from different countries in the ranking of the most preferred sources of information, motives and forms of political participation.

Conducting a correlation analysis (Pearson) made it possible to establish the existence of correlations between electoral activity, using sources for obtaining information about politics, motives and forms of political participation.

So, electoral activity of youth is correlated at a high level of significance $(\mathrm{p}<0.001)$ with:

- obtaining information from the mass media $(r=0.219)$, the Internet (blogs, forums, websites) $(r=0.142)$, the family $(r=0.180)$, political institutes $(r=0.161)$ and political parties $(r=0.171)$;

- forms of political participation: the behavior of the observer, the spectator $(r=0.336)$, participation in politics as an ordinary functionary $(r=0.161)$, alienation from politics due to the loss of trust in political institutions $(\mathrm{r}=0.230)$, the non-acceptance of the political system $(\mathrm{r}=0.219)$ and hostility towards it $(\mathrm{r}=0.231)$;

- motives of political participation: the motive of interest $(\mathrm{r}=0.249)$, the cognitive motive $(\mathrm{r}=0.283)$, the motive of the world transformation $(\mathrm{r}=0.244)$, the motive of power $(\mathrm{r}=0.124)$.

\section{Conclusions}

A study conducted on a sample of young people from 5 countries showed that respondents are ready to participate in the political life of the country not only as voters, but also as active citizens who is involved in the process of adopting and implementing policies at the local, regional and national levels.

Of great importance for young people is the perception of their participation as significant and potential, as well as the legality and fairness of the electoral process.

One of the possible obstacles for young people to involve into politics as an initiator and executor of changes may be an insufficient level of knowledge about their capabilities (participation in elections as a candidate, options and opportunities to participate in the life of their city or country). Filling this gap is repairable through the process of education and disseminating information about the possibilities of realizing not only passive but also active law, as well as attracting young people to various forms of political participation.

For young people from different countries, information about politics emanating from institutions of purposeful political socialization (government, political parties, political advertising, etc.) is not influential. The most important player in the electoral field of all countries today is Internet communication (including social networks) and the immediate environment of young people (family, friends, referent groups).

Getting young people involved in social and political life in order to gain personal experience of participation is important because it determines the beginning of their further civil development and possible inclusion in power relations, management and political decision-making processes not only to protect their interests, but also for real influence on it. 


\section{References}

Chirun, S. N. (2010). Politicheskaja aktivnost' i politicheskoe uchastie molodezhi: problemy i vozmozhnosti [Political activity and political participation of youth: problems and opportunities]. Vestnik Tomskogo gosudarstvennogo universiteta [Tomsk State University Bulletin], 332, 50-54 (in Russian).

Emmons, R. (2004) Psihologija vysshih ustremlenij: motivacija i duhovnost' lichnosti [Psychology of Higher Aspirations: Motivation and Personality Spirituality]. Ed. D.A.Leontiev. Moscow (in Russian).

Kirichek, A. I. (2011). K voprosu o differenciacii soderzhanija kategorij «politicheskaja aktivnost'», «politicheskoe povedenie», i «politicheskoe uchastie» [On the issue of differentiating the content of the categories «political activity», «political behavior» and «political participation»]. Obshhestvo: politika, jekonomika, pravo [Society: politics, economics, law], 3, 34-37 (in Russian).

Olshansky, D. V. (2001). Osnovy politicheskoj psihologii [Fundamentals of Political Psychology]. Ekaterinburg (in Russian).

Samuylova, I. A. (2013). Ustanovki studencheskoj molodezhi Sankt-Peterburga po otnosheniju $\mathrm{k}$ vyboram v Rossii kak faktor ih politicheskogo uchastija [Attitudes of young people living in Saint-Petersburg toward the elections in Russia as a factor of their political participation]. Peterburgskij psihologicheskij zhurnal [Petersburg Psychological Journal], 3 (in Russian). Retrieved 04.04.19 from: http://ppj.spbu.ru/index.php/psy/article/view/35/17

Shestopal, E. B. (2002). Politicheskaja psihologija [Political Psychology]. Moscow: INFRA-M (in Russian).

Volkov, B. S. (2006). Psikhologiya yunosti i molodosti: Uchebnoye posobiye [Psychology of youth and adolescence: Textbook]. Moscow: Akademicheskiy Proyekt: Triksta.

World Development Report 2007: Development and the Next Generation (2006). Washington, The International Bank for Reconstruction and Development / World Bank.

Wattenberg, Martin P. (2006). Is Voting for Young People? New York, NY: Longman. 